\title{
WERYFIKACJA ŚLADÓW UŻYTKOWANIA KOŚCIANYCH SZYDEŁ I STILUSÓW - STUDIUM EKSPERYMENTALNE ${ }^{1}$
}

\section{VERYFICATION OF THE USE-WEAR TRACES ON BONE AWLS AND STILUSES - AN EXPERIMENTAL STUDY}

\author{
Monika Stelmasiak \\ Instytut Archeologii. Uniwersytet im. Adama Mickiewicza w Poznaniu \\ ul. Umultowska 89D, 61-614 Poznań, Polska \\ monikastelmasiak93@gmail.com
}

\begin{abstract}
Awls have been used for perforating various types of materials from the Paleolithic to the early medieval period, until they were replaced by their metal equivalents. Though the technology of the manufacture has changed, the form remained virtually the same, containing of a handle and a shaft. Stiluses are the component of the stationery set, which also consists of the wax tablets. The latter however, very rarely preserve to our times. Bone awls and stiluses are as well the common type of relics found on the early medieval sites. Recent studies were mainly oriented on their chronological and typological classification and on determining the place of their manufacture and the place of their use. Yet, there were no attempts of conducting a use-wear analysis, which leads to the appropriate characteristic of these tools, previously obtained in a very generic way, mostly basing on their morphological features which is quite misleading, due to their overall similarity. That was an impulse to undertake research on that field. Conducted experiments and use-wear analysis resulted in obtaining an accessible way to distinguish bone awls from bone stiluses, which enabled authoress to apply this method on genuine artifacts from early medieval sites.
\end{abstract}

KEY WORDS: bone awls, bone stiluses, experiment, functional analysis, Early Medieval period

\section{WPROWADZENIE}

Użytkowanie szydeł wykonanych z kości i rogu sięga swoją tradycją paleolitu i trwa nieprzerwanie do ok. XIII wieku, gdy pojawiają się ich żelazne odpowiedniki

\footnotetext{
${ }^{1}$ Streszczenie pracy licencjackiej (Stelmasiak, 2016) pt. Weryfikacja śladów użytkowania kościanych szydet $i$ stilusów - studium eksperymentalne, napisanej pod kierunkiem dr Katarzyny Pyżewicz
} 
i współwystępują z nimi jeszcze przez pewien czas (Brzostowicz, 2002, s. 91-92). Stosowanie ich do perforacji tkanin i skór spowodowało wprowadzenie do literatury pojęć uszczegóławiających ich wykorzystanie. Terminem „kolce” określił je w swoim opracowaniu materiału kostnego z Ostrowa Tumskiego we Wrocławiu Krzysztof Jaworski (1990), zastępując tym samym pojawiające się w starszej literaturze terminy takie jak rylce, iglice czy szydła. Stosowane przez wspomnianego autora określenie miało być również formą uniknięcia niewłaściwej oceny zabytków o podobnych cechach morfologicznych, których przeznaczenie mogło być jednak inne od wyżej wymienionego. Klasyfikacja narzędzi w typie kolców na podstawie charakteru końcówki pracującej na rylce (stępione) i kolce (ostre), stosowana w starszej literaturze, to kolejny aspekt poruszony przez Jaworskiego, który wskazuje że taka powierzchowna ocena prowadzi do dalszych błędów. Stępianie się końcówki pracującej jest bowiem naturalnym procesem wynikającym z użytkowania narzędzi w typie kolców (Jaworski, 1990, Stelmasiak, 2016).

Młodszą niż szydła/kolce metryką charakteryzują się stilusy, znane już od drugiego tysiąclecia BCE (Before the Common Era), przede wszystkim z terenów Bliskiego Wschodu i basenu Morza Egejskiego. Również w przypadku tych narzędzi starsza literatura wprowadza niemały zamęt w nazewnictwie, który wynika z powierzchownej klasyfikacji na podstawie wyłącznie cech morfologicznych. Dotyczy to zarówno okazów metalowych, jak i kościanych, których charakterystyczna budowa, z przeciwległą do pracującej końcówką uformowaną w literę „T” lub „,Y” (służącą do rozmazywania wosku) oraz wstępującą niekiedy ornamentyką górnej części (interpretowaną jako zabieg zapobiegający wyślizgiwaniu się stilusa z dłoni), powodowała określanie podobnych znalezisk na stanowiskach jako szpile, sztućce czy nawet narzędzia liturgiczne (Kostrzewski, 1947; Kóčka-Krenz, 2001; Niesiołowska-Wędzka, 1972; Żak, 1956). Ponadto kolejnym czynnikiem warunkującym nieprawidłową interpretację tych zabytków jest to, że w Polsce nie występują one we wspólnym kontekście z powoskowanymi tabliczkami. Nie można jednak poddać wątpliwości nierozerwalnej relacji tych narzędzi pisarskich, a fakt rzadkiego odkrywania na stanowiskach tabula cerate jest zjawiskiem wręcz powszechnym, ze względu na wykonanie ich z ulegających szybkiemu rozkładowi materiałów organicznych (Niesiołowska-Wędzka, 1972, s. 627).

Kolejny problem stanowi podobieństwo morfologiczne szydeł/kolców i stilusów, które nie noszą wyraźnych cech dystynktywnych, jak opisane wyżej końcówki do rozmazywania wosku. Również sposób dotychczasowego traktowania materiału kostnego ze stanowisk wczesnośredniowiecznych nie przybliża rozwiązania. Badania te skupiają się przede wszystkim na opisie charakterystyki narzędzi, klasyfikacji typologicznej i chronologicznej oraz analizie archeozoologicznej. Analiza traseologiczna, która może jasno zdefiniować przeznaczenie narzędzi na podstawie badań śladów użytkowych, wciąż nie jest metodą popularną, czego główną przyczyną jest brak materiałów porównawczych na stanowiskach archeologicznych (Makowiecki, Winiarska-Kabacińska, 2004, s. 556). 
Stosowanie metody eksperymentalnej i traseologicznej w badaniach materiałów kostnych w polskiej archeologii podjęli się pojedynczy badacze, m.in. Mateusz Frankiewicz (2011, 2013) czy Marcin Diakowski (2014). Ich dorobek dotyczy jednak szerokiego zakresu narzędzi odnoszącego się do starszych okresów.

Autorka w swojej pracy zaproponowała model rozszerzenia badań nad kościanymi kolcami/szydłami i stilusami pozyskiwanymi ze stanowisk wczesnośredniowiecznych o aspekt funkcjonalny tych narzędzi. Wyniki badań uzyskane metodą eksperymentalną i traseologiczną mają stanowić bazę porównawczą dla szydeł oraz stilusów z podokresu wczesnego średniowiecza, pozyskiwanych w Polsce, w odniesieniu do zakończonych, trwających oraz planowanych badań.

\section{ZAŁOŻENIA EKSPERYMENTU}

Przystępując do planowania eksperymentu, autorka posiłkowała się przede wszystkim pracami Petera Kelterborn'a (2005) oraz Johna Coles'a (1973, 1997), którzy prezentują ogólne zasady prowadzenia doświadczeń archeologicznych (ryc. 1). John Coles w swojej pracy z 1973 roku wysnuwa tezę o marginalnym znaczeniu kościanych szydeł $w$ badaniach traseologicznych opartych na ich rzekomych, łatwych do identyfikacji cechach morfologicznych. Przesunięcie na drugi plan badań doświadczalnych na materiale kostnym zauważa on też w swojej pracy z 1997 roku (Experimental Archaeology. W: The First International Symposium on Wood Tar and Pitch), gdzie podkreśla, że pierwsze dekady stosowania w archeologii metody eksperymentalnej skupiały się głównie na budownictwie prahistorycznym, garncarstwie, szkutnictwie, metalurgii i przede wszystkim na krzemieniarstwie.



Ryc. 1. Uproszczona trajektoria eksperymentu (za Coles, 1997, s. 309)

Fig. 1. Simplified trajectory of the experiment (Coles, 1997, p. 309) 
Autorka oparła swój proces eksperymentu na modelu zaproponowanym przez Isabelle Sidéra i Aleksandrę Legrand (2006). Badaczki zamknęły go w czterech punktach. Pierwszym z nich jest EKSPERYMENT, rozpoczynający się od pozyskania odpowiednich form artefaktów i wykonania ich replik, które później należy wielokrotnie użytkować w celu wytworzenia konkretnego śladu. Drugi punkt stanowi ANALIZA FUNKCJONALNA, w trakcie której ma miejsce ustalenie prawdopodobnego zastosowania badanego przedmiotu. Punkt trzeci to ANALIZA MAKROSKOPOWA, w której dokonuje się obserwacji bez użycia dużych powiększeń. Ostatni element tego modelu stanowi ANALIZA MIKROSKOPOWA, wykorzystująca duże powiększenia i korektę komputerową do badania śladów użytkowych.

Aplikacja modelu Legrand i Sidéry (2006) pozwoliła autorce wypracować założenia eksperymentu, który stanowi najistotniejszy element badania. Pierwszym z postawionych w pracy celów jest sprawdzenie, czy istnieje możliwość wyraźnego oddzielenia szydeł od stilusów nienoszących dystynktywnych cech morfologicznych. Następny istotny element stanowi analiza śladów użytkowych materiałów wykorzystanych w eksperymencie. Trzecim z założeń jest weryfikacja śladów podepozycyjnych na narzędziach nieużytkowanych, jako ewentualnych analogii dla narzędzi noszących ślady użytkowe. Ostatnim założeniem, i tym samym głównym celem pracy, jest stworzenie bazy porównawczej dla przyszłych badań materiałów kostnych ze stanowisk wczesnośredniowiecznych (Stelmasiak, 2016).

Aby przeprowadzone eksperymenty stanowiły rzetelną bazę danych, każdy z nich został wykonany kilkakrotnie, w celu eliminacji zdarzeń przypadkowych (Korobkova, 1999, s. 15). W badaniu obserwacji podlegały końcówki pracujące replik narzędzi przeznaczonych do poszczególnych czynności. Na bieżąco odnotowywane były obserwacje makroskopowe dotyczące uszkodzeń mechanicznych na narzędziach, takich jak wykruszenia i zatępienia.

Wśród spodziewanych w trakcie analizy funkcjonalnej śladów znajdują się tzw. „pseudoślady”, stanowiące efekt zalegania w warstwie kulturowej. W trakcie obróbki skóry i tkanin na powierzchni mogą wystąpić: rozjaśnienie części pracującej, wyświecenia, ślady liniowe, przeszlifowania, zniekształcenia i zatępienia oraz zagładzenia części obuchowej (Korobkova, 1999, s. 62-63, 88-89). W przypadku stilusów nie można było mówić o spodziewanym charakterze śladów użytkowych, jednak pewna była jego obserwacja tylko na końcówce pracującej, ponieważ tylko na niej skupiały się czynności związane z eksperymentem.

\section{MATERIALY WYKORZYSTANE W EKSPERYMENCIE}

W eksperymencie wykorzystanych zostało 20 replik kościanych kolców (ryc. 2), z którego każde poddano działaniu jednego lub więcej czynników. Zabieg ten pozwolił na wyodrębnienie pewnych pożądanych na narzędziach śladów. Kolce/szydła/ 


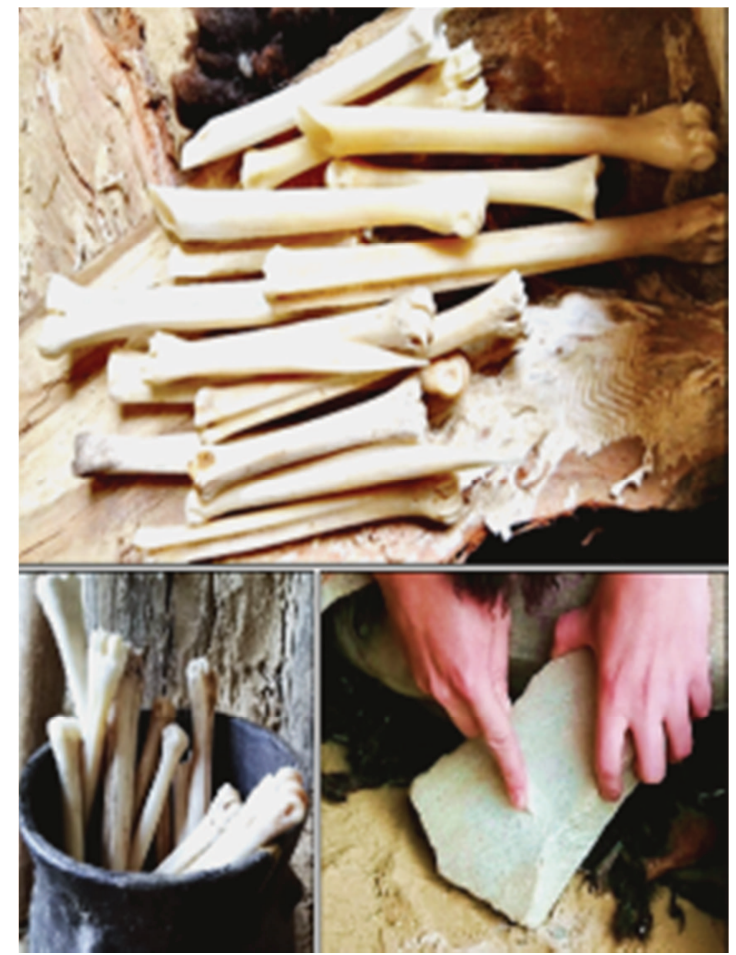

Ryc. 2. Kości owcy wrzosówki oraz sarny w trakcie obróbki. Fot. Filip Banach

Fig. 2. Sheep's and roe's bones during the experiment. Photo Filip Banach

/stilusy wykorzystane w eksperymencie wykonano z kości śródręcza oraz kości rysikowych owcy wrzosówki (większość) i sarny.

Repliki wykonane zostały przez panów Wojciecha i Andrzeja Kawczyńskich z Muzeum Archeologicznego w Biskupinie. Po mechanicznym oczyszczeniu kości zostały zmiękczone. Ze znanych w średniowieczu metod zmiękczania kości, takich jak ich ługowanie na gorąco lub nacieranie tłuszczem, wybrano ich wygotowanie i długotrwałe moczenie w wodzie (Kostrzewski, 1946, s. 12). Dodatkowym zabiegiem było moczenie replik w roztworze wody i proszku w celu ich wybielenia. Tak przygotowane kości mogły zostać pocięte (aby uformować pożądaną końcówkę pracującą), a następnie oszlifowane na płycie z piaskowca (bez podsypki), aby nadać im finalny kształt.

Ostatnim zabiegiem związanym z obróbką kości było doczyszczenie resztek pozostających w ich wnętrzu za pomocą drewnianego patyczka, co pozwoliło uniknąć procesów gnilnych, które mogłyby zaburzyć przebieg eksperymentu.

Uzupełnieniem do kościanych replik były również materiały przebijane w eksperymencie. Stanowiły one kilka rodzajów skór, futro owcy wrzosówki oraz tkaniny 
lniane o różnej gęstości. Dodatkowym elementem była płyta z piaskowca, na której dokonano wstępnego oszlifowania narzędzi. W eksperymencie poświęconym stilusom wykorzystano drewnianą tabliczkę z naniesioną warstwą barwionej na czarno parafiny. Etap poświęcony śladom podepozycyjnym wymagał wykorzystania skrzyni ze zróżnicowanym sedymentem, składającym się z fragmentów ceramiki, węgla drzewnego, kamieni oraz ziemi.

Przed przystąpieniem do badań autorka nadała replikom numery oraz przypisała je do odpowiednich grup o zróżnicowanej wielkości. Wynikiem tego działania było wyróżnienie sześciu grup testowych.

Grupa pierwsza, składająca się z 5 replik, posłużyła do sprawdzenia podstawowego przeznaczenia kolców/szydeł, czyli perforacji skór. Wykorzystane zostały skóry bydlęce o różnej twardości, garbowane roślinnie skóry cielęce oraz futra. Dodatkowo, w celach bezpieczeństwa oraz ułatwienia pracy, użyta została naturalna dębowa podkładka.

Druga grupa (5 replik) przeznaczona została do przebijania lnianej tkaniny naturalnej i farbowanej. Choć to zastosowanie szydeł, podobnie jak rozdzielanie włókien lnu, jest zdecydowanie rzadszą praktyką, nie mogło ono zostać pominięte w eksperymencie. Aby zintensyfikować efekty wykonywanych czynności, kolce/szydła przetykane były przez potrójną warstwę materiału.

Trzecią grupę (5 replik) stanowiły rylce/stilusy, które posłużyły do wykonania serii napisów na pokrytej woskiem pisarskim drewnianej tabliczce. Jak wspomniano wyżej, do wykonania tabliczki wykorzystano barwioną parafinę, zastępując tym występującą zwyczajowo na tego typu znaleziskach powłokę wykonaną z wosku pszczelego z barwnikami i tłuszczami ułatwiającymi rozmazywanie napisów.

Grupa czwarta, złożona z dwóch replik, została poddana szlifowaniu na mokrej płycie z piaskowca, bez stosowania podsypki mineralnej. Po dodatkowym zaostrzeniu końcówek pracujących oraz brzegów powierzchni narzędzi zostały one wykorzystane w grupie VI.

W piątej grupie pozostawione zostały trzy repliki, które z wyłączeniem śladów powstałych $\mathrm{w}$ trakcie wstępnej obróbki nie nosiły śladów użytkowania. Stanowić miały bazę „,czystych” okazów służących analizie porównawczej. Narzędzia z tej grupy również zostały wykorzystane w grupie VI.

Ostatnia grupa (5 replik) została złożona $\mathrm{z}$ grup IV oraz V. Repliki złożono w skrzyni ze zróżnicowanym sedymentem i zakopano na ruchliwej ścieżce prowadzącej do „Wioski Wczesnopiastowskiej” w Muzeum Archeologicznym w Biskupinie na okres dwóch tygodni.

\section{PRZEBIEG ESKSPERYMENTU}

W trakcie przeprowadzania eksperymentu była prowadzona jednocześnie analiza makroskopowa replik oraz materiałów towarzyszących eksperymentom. 
Eksperyment w grupie pierwszej (skóry) trwał łącznie ok. 7 h. Już w przypadku pierwszej repliki dokonano spostrzeżenia, że bardziej miarodajny efekt przynosi ruch przypominający wwiercanie się niż przebijanie skóry. We wszystkich przypadkach mocne uderzenia pozostawiły ślady na dębowej podkładce. Najczęstszym uszkodzeniem mechanicznym w tej grupie było ukruszenie końcówki pracującej, złamanie i stępienie uniemożliwiające dalszą pracę.

Każdej z replik w drugiej grupie (tkaniny lniane) poświęcono ok. 1,5 h pracy. $\mathrm{W}$ przeciwieństwie do pierwszego zestawu narzędzi wykorzystanych w eksperymencie, przebijanie się przez warstwy lnu przynosiło miarodajny efekt, nie było więc konieczności „wwiercania” się w materiał, jak w przypadku skór (ryc. 3). Również w tej grupie najczęstszą formą uszkodzeń mechanicznych było ukruszenie się czy stępienie końcówki pracującej, jednak w przypadku żadnej z replik nie uniemożliwiło to dalszej pracy.



Ryc. 3. Przekłuwanie materiałów Inianych oraz skóry. Fot. Łukasz Krasula

Fig. 3. Perforation of linen and hides. Photo Łukasz Krasula 
Stosunkowo krótszy czas pracy został poświęcony stilusom (od 30 min do $1 \mathrm{~h}$ ). Wśród obserwacji istotną uwagę stanowi to, że powierzchnia stilusa pokrywała się topniejącym w ręce woskiem. Nie odnotowano w tej grupie żadnych uszkodzeń mechanicznych, poza wyraźnym zaokrągleniem końcówki pracującej.

Dwóm replikom poddanym ponownemu szlifowaniu na płycie z piaskowca poświęcono zaledwie po $10 \mathrm{~min}$. Ten czas jednak w zupełności wystarczył, aby w obu przypadkach zarejestrować zaostrzenie końcówki pracującej i boków narzędzi oraz ich wyraźne skrócenie o ok. $1 \mathrm{~cm}$.

Ostatnia grupa, składająca się z replik grup czwartej i piątej, wkopana została w skrzyni ze zróżnicowanym sedymentem na dwa tygodnie na ruchliwej ścieżce. Zabieg deptania miał w założeniu przyspieszyć działanie procesów podepozycyjnych. Ten etap eksperymentu wymaga jednak znacznie dłuższego czasu, dlatego zostanie on powtórzony. Niewielkie uszkodzenia mechaniczne odnotowano tylko w przypadku dwóch replik.

\section{ANALIZA TRASEOLOGICZNA}

Każda $\mathrm{z}$ replik przed analizą śladów użytkowych została przygotowana według zaleceń S. A. Semenova (1967, s. 24-26) przez przetarcie jej spirytusem w celu „wydobycia” śladów użytkowych. Obserwacje natomiast prowadzone były w trzech zalecanych przez A. Legrand i I. Sidéra (2007, s. 72-75) miejscach: na końcówce pracującej, na powierzchni narzędzia, w części obuchowej - gdzie zanikać mają ślady użytkowe.

\section{Analiza makroskopowa}

Pierwszym etapem analizy funkcjonalnej jest obserwacja śladów użytkowych na poziomie makroskopowym. Jest to uzupełnienie podsumowania obserwacji prowadzonych w trakcie przeprowadzania eksperymentów.

Repliki wykorzystane w grupie pierwszej charakteryzują się wyraźnymi wyświeceniami i rozjaśnieniami na powierzchni końcówki pracującej. W części obuchowej uwidaczniają się natomiast ślady zagładzenia. Na bokach ostrza pracującego widoczne są natomiast rozchodzące się ukośnie ślady liniowe.

Druga grupa replik pod względem obserwowalnych ,gołym okiem” śladów prezentuje się podobnie do grupy pierwszej. Końcówki pracujące noszą wyraźne wyświecenia, których intensywność niknie im bliżej części obuchowej. Również w tej grupie widoczne są ukośne ślady liniowe rozchodzące się od ostrza końcówki pracującej, jednak znacznie mniej intensywne niż w przypadku replik wykorzystywanych do przekłuwania skór. 
Grupę replik wykorzystanych w eksperymencie jako stilusy charakteryzuje wyraźne zmatowienie powierzchni w części pracującej oraz zagładzenia części obuchowej, będące wynikiem topienia się wosku pozostającego na dłoni. Wyraźne jest zaokrąglenie końcówki pracującej.

Czwarta grupa nosi bardzo wyraźne ślady przeszlifowań, widocznych bardzo dobrze już na poziomie makroskopowym jako ukośne zmatowienia powierzchni.

W grupie szóstej (składającej się z grup IV i V) nie odnotowano żadnych wyraźnych makroskopowo śladów na powierzchni narzędzi.

\section{Analiza mikroskopowa}

Do analizy funkcjonalnej wykorzystany został mikroskop metalograficzny Nikon Eclipse LV150, działający przy użyciu światła odbitego, o powiększeniach rzędu 50-500×. Najlepsze efekty przynosiła obserwacja przy wykorzystaniu największego natężenia światła oraz powiększenia rzędu 50×-100×. Dokumentację wykonano przy pomocy aparatu Canon PowerShot A620, a następnie poddano obróbce cyfrowej.

Grupa replik przeznaczona do perforacji materiałów lnianych uwydatniła w badaniu z wykorzystaniem dużych powiększeń te same cechy, które zaobserwowano
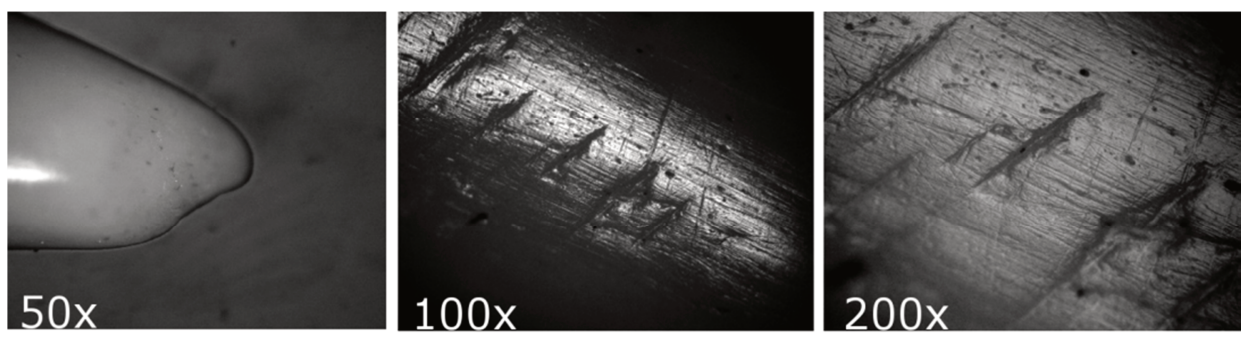

Ryc. 4. Analiza funkcjonalna - replika nr 8 (skóry). Fot. Monika Stelmasiak

Fig. 4. Functional analysis - replica No. 8 (hides perforation). Photo Monika Stelmasiak
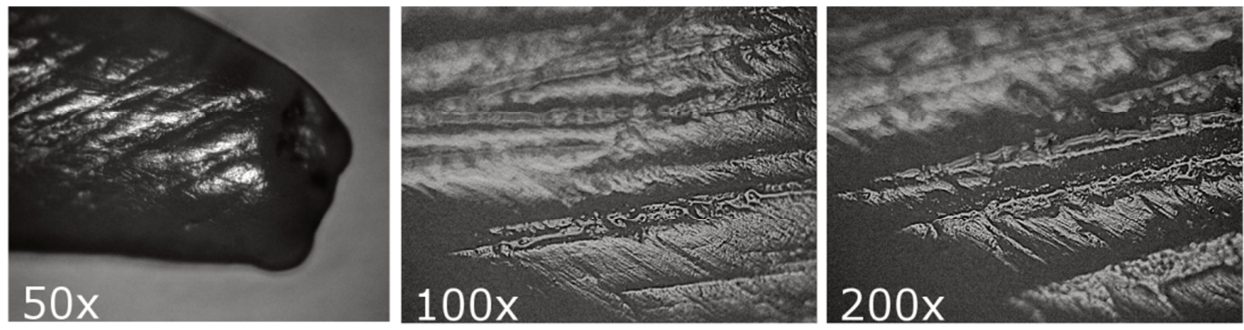

Ryc. 5. Analiza funkcjonalna - replika nr 11 (skóry). Fot. Monika Stelmasiak

Fig. 5. Functional analysis - replica No. 11 (hides perforation). Photo Monika Stelmasiak 
już na poziomie makroskopowym. Ich zestaw jest bardzo podobny do tego, który występuje na narzędziach związanych z obróbką skóry, są to jednak ślady o wiele delikatniejsze. Występujące na narzędziach wyświecenia wchodzą w strukturę narzędzia w znacznie mniejszym stopniu niż w przypadku grupy I. Charakter wyświeceń można określić jako ,jaskrawy”. Rozchodzące się na powierzchni pracującej ślady liniowe również są mniej wyraźne (ryc. 6, 7). Różnice te wywołane są z pewnością odmienną twardością materiałów przebijanych w omawianych grupach. Dodatkową obserwacją było odnotowanie w kilku przypadkach pozostałości nici w szczelinach kości.
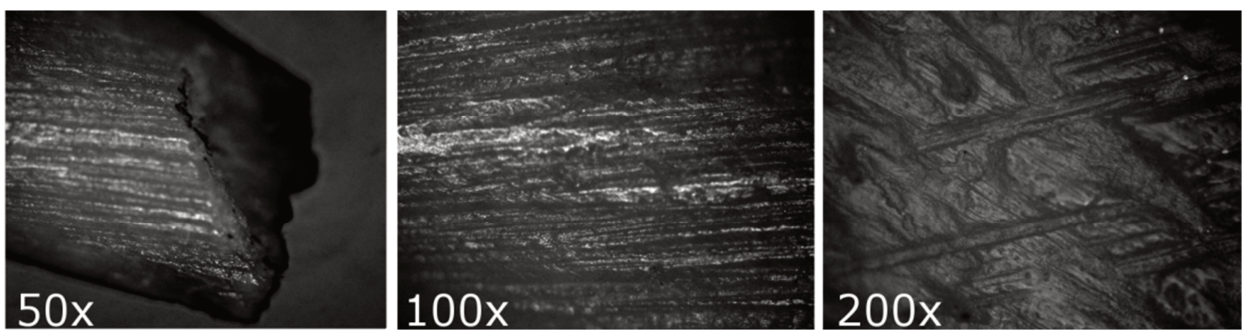

Ryc. 6. Analiza funkcjonalna - replika nr 7 (len). Fot. Monika Stelmasiak

Fig. 6. Functional analysis - replica No. 7 (linen perforation). Photo Monika Stelmasiak
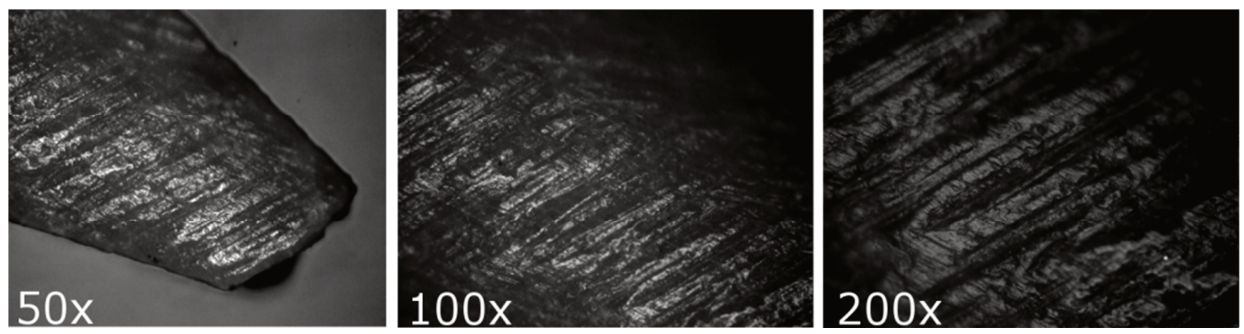

Ryc. 7. Analiza funkcjonalna - replika nr 15 (len). Fot. Monika Stelmasiak

Fig. 7. Functional analysis - replica No. 15 (linen perforation). Photo Monika Stelmasiak

Istotną uwagą dla grup I i II jest charakter uszkodzeń końcówki pracującej, manifestujący się w dużych powiększeniach jako nieregularny, ,poszarpany” charakter krawędzi, nieodnotowany w pozostałych grupach.

Repliki wykorzystane do pisania na powoskowanych tabliczkach nie uwydatniły dystynktywnych cech na poziomie makroskopowym (zmatowienie powierzchni wynikające $\mathrm{z}$ zabrudzenia topniejącym $\mathrm{w}$ dłoni woskiem oraz delikatne zaokrąglenie końcówki pracującej). Zastosowanie dużych powiększeń pozwoliło jednak odnoto- 
wać we wszystkich przypadkach w tej grupie bardzo ważną cechę dystynktywną, która pozwala w łatwy sposób identyfikować kościane stilusy - charakter końcówki pracującej (ryc. 8, 9). Obserwowalne na poziomie makroskopowym zaokrąglenie w dużych powiększeniach prezentuje się jako wyraźne stępienie, „wduszone” w pozostałą część narzędzia, co przypomina w pewien sposób stalówkę pióra wiecznego. Przebieg krawędzi we wszystkich przypadkach jest łagodny, niepostrzępiony. Na powierzchni narzędzi nie występują ślady liniowe, zaobserwować można natomiast pojedynczo występujące punktowe wyświecenia. Wyniki pozyskane w tej grupie są szczególnie istotne dla identyfikacji zabytków kościanych w typie stilusów na stanowiskach wczesnośredniowiecznych.
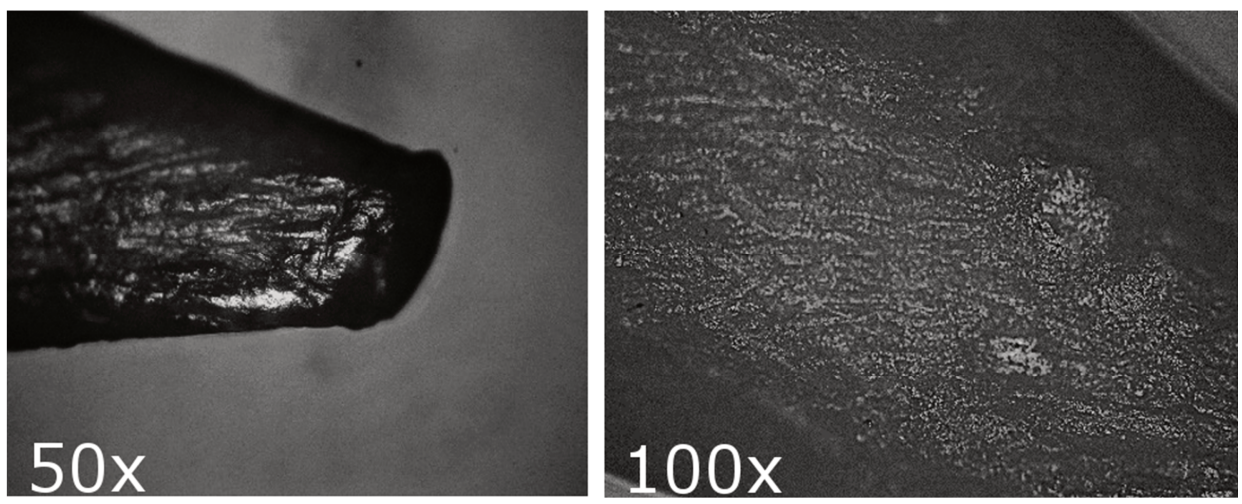

Ryc. 8. Analiza funkcjonalna - replika nr 1 (stilus). Fot. Monika Stelmasiak

Fig. 8. Functional analysis - replica No. 8 (stilus). Photo Monika Stelmasiak
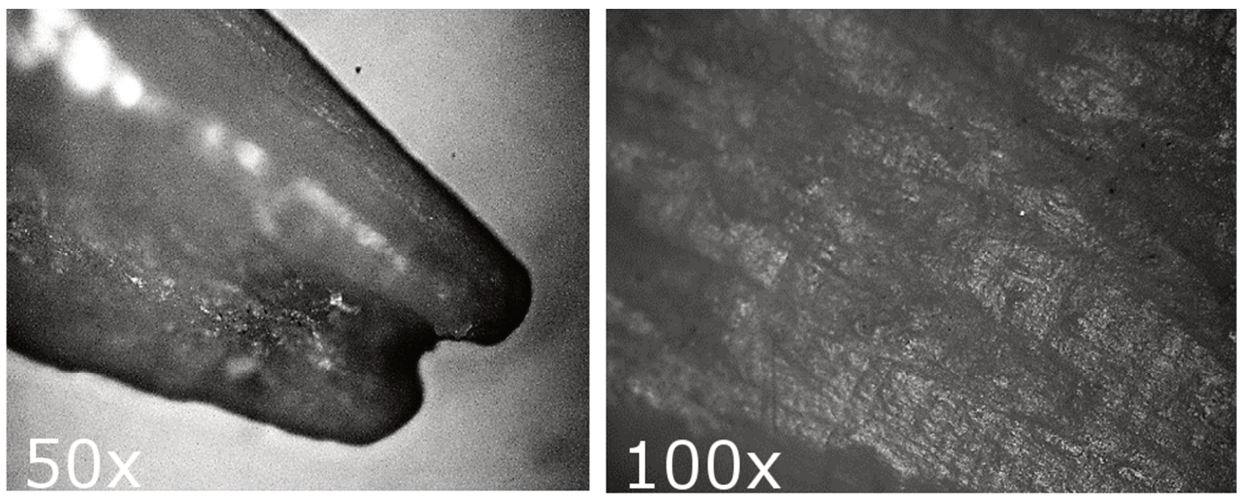

Ryc. 9. Analiza funkcjonalna - replika nr 6 (stilus). Fot. Monika Stelmasiak

Fig. 9. Functional analysis - replica No. 8 (stilus). Photo Monika Stelmasiak 

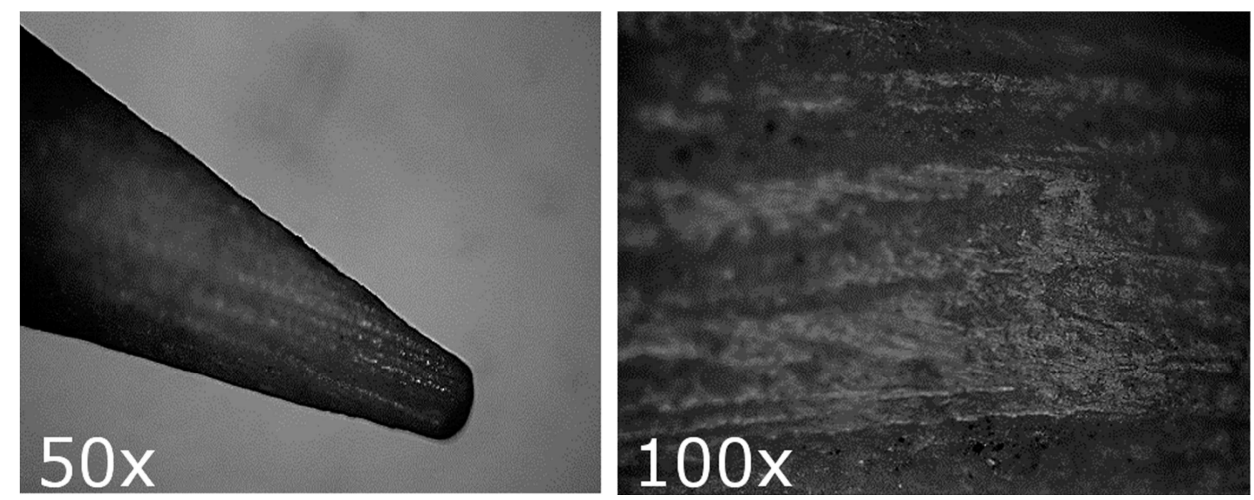

Ryc. 10. Analiza funkcjonalna - replika nr 12 (ślady podepozycyjne). Fot. Monika Stelmasiak

Fig. 10. Functional analysis - replica No. 12 (post-depositional processes). Photo Monika Stelmasiak
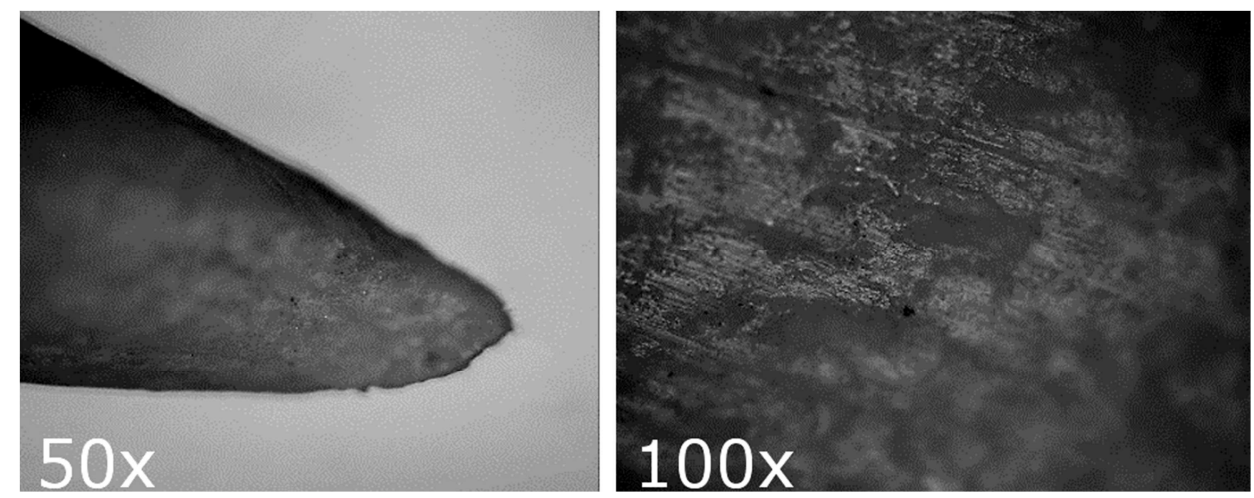

Ryc. 11. Analiza funkcjonalna - replika nr 19 (ślady podepozycyjne). Fot. Monika Stelmasiak

Fig. 11. Functional analysis - replica No. 19 (post-depositional processes). Photo Monika Stelmasiak

Grupa VI, związana z wpływem procesów podepozycyjnych, okazała się źródłem cennych obserwacji na temat zastosowania metody traseologicznej do narzędzi w typie kolców/szydeł i stilusów. Obserwacje poczynione na poziomie makroskopowym nie ulegają większym zmianom przy wykorzystaniu dużych powiększeń. Pewnymi śladami charakteryzują się dwie repliki, szlifowane dodatkowo na płycie z piaskowca (drobne deformacje końcówek pracujących). Żadne jednak z wykorzystanych w tej grupie kolców/szydeł nie ma pseudośladów będących charakterystyczną cechą zalegania w warstwie kulturowej (ryc. 12, 13). Powyższe obserwacje wskazują wyraźnie, że przy założeniu idealnych warunków depozycji zabytków jest możliwe odczytanie śladów użytkowych z tych narzędzi, bez dodatkowych zaburzeń na powierzchni. 


\section{WNIOSKI W KONTEKŚCIE DANYCH ŹRÓDŁOWYCH}

Przeprowadzone przez autorkę eksperymenty oraz analiza funkcjonalna narzędzi kościanych w typie kolców/szydeł i stilusów jest propozycją uporządkowania niesprecyzowanego sposobu klasyfikacji tych narzędzi, którą prowadzono dotychczas na stanowiskach wczesnośredniowiecznych. Efektem jest stworzenie bazy dystynktywnych cech użytkowych, możliwych do zaobserwowania przy wykorzystaniu dużych powiększeń, które pozwalają na łatwą identyfikację tych zabytków.

Istotny okazał się etap obserwacji procesów podepozycyjnych, który potwierdził możliwość niezaburzonego odczytu śladów na powierzchni pracującej narzędzi, co umożliwia zastosowanie tej metody na oryginalnych zabytkach ze stanowisk wczesnośredniowiecznych.

Połączenie metody eksperymentalnej i traseologicznej pozwoliło wypracować system, który pomoże uporządkować pozyskiwane na wczesnośredniowiecznych stanowiskach zabytki szydeł i stilusów na podstawie nie tylko, niekiedy mocno mylących, cech morfologicznych, co w znaczny sposób pomoże uporządkować również nazewnictwo (zwłaszcza w odniesieniu do starszej literatury).

Niezwykle istotne obserwacje śladów użytkowych dla kościanych szydeł/kolców pozwolą doprecyzować w opracowaniach, do jakiego rodzaju materiałów były one wykorzystywane.

Najważniejszym jednak osiągnięciem przeprowadzonych badań jest opracowanie identyfikacji cech dystynktywnych na końcówkach pracujących kościanych stilusów. Ich charakterystyczna, obserwowalna w dużych powiększeniach forma pozwoli ponownie zweryfikować egzemplarze uznane za stilusy ze względu na swoją budowę (z charakterystyczną, przeciwległą do pracującej końcówką do rozmazywania wosku) lub występującą na nich niekiedy ornamentyką. W ten sam sposób ponownej weryfikacji poddane mogą zostać zabytki, które mogą być stilusami, ale ze względu na swoje cechy morfologiczne zostały uznane za iglice (okazy z otworem w górnej części) czy ozdobne szpile.

Autorce udało się osiągnąc wszystkie założenia eksperymentu, tworząc bazę dystynktywnych cech dla poszczególnych narzędzi i wykonywanych nimi czynności, co przysłużyć może się w klasyfikacji narzędzi wczesnośredniowiecznych w typie kolców/szydeł i stilusów zarówno z zamkniętych, wciąż prowadzonych jak i przyszłych badań.

\section{BIBLIOGRAFIA}

Antowska-Gorączniak O.

2005 Przedmioty z kości i poroża z Ostrowa Tumskiego w Poznaniu. W: H. Kóčka-Krenz (red.), Poznań we wczesnym średniowieczu (T. 5, s. 215-232). Poznań: Wydawnictwo Poznańskie. 
Anotwska-Gorączniak O.

2016 Katalog zabytków. W: M. Przybył (red.), Archeologiczne tajemnice palatium i katedry poznańskiego Ostrowa (s. 142-147). Poznań: Muzeum Archeologiczne w Poznaniu.

Brzostowicz M.

2002 Bruszczewski zespót osadniczy we wczesnym średniowieczu. Poznań: Poznańskie Towarzystwo Przyjaciół Nauki.

Carver M.

2005 Experimental archaeology. W: C. Renfrew i P. Bahn (red.), Archaeology the key concepts (s. 83-86). London - New York: Routledge.

Cnotliwy E.

1956 Z badań nad rzemiosłem zajmującym się obróbką rogu i kości na Pomorzu Zachodnim we wczesnym średniowieczu. Materiaty Zachodniopomorskie, 2, s. 195-229.

Cnotliwy E.

1958 Wczesnośredniowieczne przedmioty z rogu i kości z Wolina, ze stan. 4. Materiały Zachodniopomorskie, 4, s. 195-229.

Cnotliwy E.

1973 Rzemiosło rogownicze na Pomorzu wczesnośredniowiecznym. Wrocław - Warszawa Kraków - Gdańsk: Państwowa Akademia Nauk.

Cnotliwy E.

2013 Przedmioty z poroża i kości z Janowa Pomorskiego (T. 2). Elbląg: Muzeum Archeologiczne.

Coles J.

1973 Archaeology by experiment. Londyn: Routledge.

Coles J.

1997 Experimental archaeology. W: W. Brzeziński i W. Piotrowski (red.), Proceedings to the first international symposium on wood tar and pitch (s. 307-310). Warszawa: Państwowe Muzeum Archeologiczne.

Comis L.

2010 Experimental Archaeology: Methodology and new perspectives in Archaeological Open Air Museums. Journal for (Re)construction and Experiment in Archaeology, 7, s. 9-12.

Diakowski M.

2011 Analiza traseologiczna materiału kostnego ze stanowiska nr 8 w Magnicach, gm. Kobierzyce. Archeologiczne Zeszyty Autostradowe 11, Badania na autostradzie A4, 9, s. $161-170$.

Diakowski M.

2014a Przedmioty wykonane z kości i poroża. Badania traseologiczne i analiza funkcji. W: T. Stolarczyk i J. Baron (red.), Osada kultury pól popielnicowych w Grzybianach koło Legnicy (s. 345-392). Legnica - Wrocław: Muzeum Miedzi.

Diakowski M.

2014b Metoda traseologiczna i eksperymentalna w określeniu technologii i funkcji przedmiotów kościanych ze stanowiska nr 1 w Lizawicach, pow. Oławski. Śląskie Sprawozdania Archeologiczne, 56, s. 17-140.

Filipowiak W., Stanisławski B.

2013 Wolin wczesnośredniowieczny (T. 1). Warszawa: Trio.

Frankiewicz M.

2013a Analiza traseologiczna materiałów kostnych. W: M. Przybyła (red.), Koszyce, stanowisko 3. Przemoc i rytuat u schyłku neolitu (s. 201-206). Kraków - Pękowice: ProfilArcheo. 
Frankiewicz M.

2013b Aplikacja metody mikroskopowej analizy powierzchni materiałów kostnych i jej możliwości na przykładzie schyłkowo-paleolitycznych i mezolitycznych znalezisk z terenu dzisiejszej pótnocnej Polski [Maszynopis pracy magisterskiej, Uniwersytet im. Adama Mickiewicza w Poznaniu].

Fullagar R.

2006 Residues and Usewear. W: J. Balme i Paterson A. (red.), Archaeology in Practice: A Student Guide to Archaeological Analyses (s. 207-234). Wiley - Blackwell.

Gąssowski J.

1955 Wczesnośredniowieczny rylec do pisania z Biskupina. Wiadomości Archeologiczne, 22/2, s. 195-196.

Jaworski K.

1990 Wyroby z kości i poroża w kulturze wczesnośredniowiecznego Ostrowa Tumskiego we Wrocławiu. Wrocław - Warszawa: Oficyna Wydawnicza Volumen.

Kelterborn P.

2005 Principles of experimental research in archaeology (summary of three previous publications by Peter Kelterborn). EuroREA, 2, s. 120-122.

Korobkova G. F.

1999 Narzędzia w pradziejach. Podstawy badania funkcji metoda traseologiczna. Toruń: Wydawnictwo Uniwersytetu Mikołaja Kopernika.

Kóčka-Krenz H.

2001 Archeologiczne świadectwa o początkach szkolnictwa w Poznaniu. Kronika Miasta Poznania, 4, s. 7-13.

\section{Kóčka-Krenz H.}

2012 Na wyspie Ostrów, przy której dziś jest Poznań. Poznań: Muzeum Archeologiczne w Poznaniu.

Lasota-Moskalewska A.

1997 Podstawy archeozoologii. Szczątki ssaków. Warszawa: Polskie Wydawnictwo Naukowe.

Lasota-Moskalewska A., Świeżyński K.

1975 Wykopaliskowe kości zwierzęce. Stan zachowania a wartość źródłowa. KHKM, 23, s. 269-277.

Laughlin J.P., Kelly R.L.

2010 Experimental analysis of the practical limits of lithic refitting. Journal of Archaeological Science, 87, s. 427-433.

Lisowski M., Pyżewicz K., Frankiewicz M.

2015 Analiza funkcjonalno-technologiczna artefaktów wykonanych z kości, poroża i zębów. W: A. Marciniak i I. Sobkowiak-Tabaka (red.), Kopydtowo, Stanowisko 6, Osady neolityczne z pogranicza Kujaw i Wielkopolski (s. 245-264). Poznań - Pękowice: ProfilArcheo.

Legrand A.

2010 The impact of insularity on morphologies and techniques. The acermaic neolithic bone tools form Khirokitia (Cyprus). W: A. Legrand i I. Sidéra (red.), Ancient and Modern Bone Artefacts form America to Russia - Cultural, technological and functional signature (s. 7-15). Oxford: British Archaeological Reports.

Legrand A., Sidéra I.

2006 Tracéologie fonctionnelle des matières osseuses: une méthode. Bulletin de la Société préhistorique française, 103/2, s. 291-304. 
Legrand A., Sidéra I.

2007 Methods, Means, and Results when Studying European Bone Industries. W: Ch. Gates St-Piere i R. B. Walker (red.), Bones as tools: current methods and interpretations in worked bone studies (s. 67-79). Oxford: British Archeological Reports.

Maigrot $\mathrm{Y}$.

2005 Ivory, bone and antler tools production systems at Chalain 4 (Jura, France): late Neolithic site, 3rd millennium. W: H. Luik, A. M. Choyke, C. E. Batey, L. Lõugas (red.), From Hooves to Horns, from Mollusc to Mammoth. Manufacture and Use of Bone Artefacts from Prehistoric Times to the Present. Proceedings of the $4^{\text {th }}$ Meeting of the ICAZ Worked Bone Research Group at Tallin, 26th-31st of August 2003 (s. 113-126). Tallin: Tallin Book Printers Ltd.

Matuszewska-Kola W.

2000 Przedmioty z poroża i kości. WMOL, s. 201-207.

Niesiołowska-Wędzka A.

1972 Rylce. Stownik Starożytności Stowiańskich, 4(2), s. 627.

Osipowicz G.

2005 Metody rozmiękczania kości i poroża w epoce kamienia w świetle doświadczeń archeologicznych oraz analiz traseologicznych. Toruń: Marszałek.

Osipowicz G.

2007 Bone and Antler Softening techniques in prehistory of the North Eastern part of the Polish Lowlands in the light of experimental archaeology and micro trace analysis. EuroREA, 4, s. 1-22.

Osypińska M.

2013 Zwierzęta w gospodarce wczesnośredniowiecznego Szczecina (s. 57-152). Poznań: Instytut Archeologii I Etnologii Polskiej Akademii Nauk.

Semenov S. A.

1964 Prehistoric technology - an experimental study of the oldest tools and artefacts from

Struckmeyer K. traces of manufacure and wear. Londyn: Barnes \& Noble.

2011 The bone tools from the dwelling mound Feddersen Wierde, Germany, and their functions. W: J. Baron, B. Kufel-Diakowska (red.), Written in Bones. Studies on technological and social context of past faunal skeletal remains (s. 187-195). Wrocław: Instytut Archeologii Uniwersytetu Wrocławskiego.

Stelmasiak M.

2016 Weryfikacja śladów użytkowania kościanych szydet i stilusów - studium eksperymentalne [Praca licencjacka, Instytut Archeologii Uniwersytetu im. Adama Mickiewicza w Poznaniu].

Winiarska-Kabacińska M.

1993 Analiza funkcjonalna ostrza kościanego zbrojonego krzemiennymi wkładkami z Tłokowa, woj. olsztyńskie. Archeologia Polski, 38(1), s. 89-93.

Winiarska-Kabacińska M., Makowiecki D.

2004 Analiza technologiczna i funkcjonalna zabytków kościanych z osad ludności pucharów lejkowatych w Pieckach i Bachorcach, woj. kujawsko-pomorskie. W: J. Bednarczyk, A. Kośko (red.), Od dtugiego domu najstarszych rolników do dworu staropolskiego. Wyniki badań archeologicznych na trasach gazociagów Mogilno - Włocławek i Mogilno - Wydartowo (s. 553-563). Poznań: Wydawnictwo Poznańskie.

Vitezović S.

2011 The neolithic bone indutry form Drenovac, Serbia. W: J. Baron i B. Kufel-Diakowska (red.), Written in bones. Studies on technological and social context of past faunal skeletal remains (117-136). Wrocław: Instytut Archeologii Uniwersytetu Wrocławskiego. 
Vitezović S.

2014 Antler as raw matieral in Starčevo culture. W: S. Vizetović i D. Antonović (red.), Archaeotechnology: studying technology from prehistory to the Middle Ages (151-176). Belgrad: Srpsko arheološko društvo Beograd.

Żak J.

1954 Wczesnośredniowieczne rylce do pisania na tabliczkach woskowych. Dawna Kultura czasopismo kwartalne Polskiego Towarzystwa Archeologicznego, 1, s. 15-16.

Żak J.

1956 Z dziejów pisma w Polsce. Slavia Antiqua, 5, s. 377-398.

Żak J.

1960 Rylec do pisania na tabliczkach powoskowanych z Pomorza. Materiaty ZachodnioPomorskie, 6, s. 241-244.

Żurowski K.

1974 Zmiękczanie poroży i kości stosowane przez wytwórców w starożytności i we wczesnym średniowieczu. Acta Universitatis Nicolai Copernici, Archeologia, 60, s. 3-23.

\title{
VERYFICATION OF THE USE-WEAR TRACES ON BONE AWLS AND STILUSES - AN EXPERIMENTAL STUDY
}

\author{
S u m m a r y
}

This paper was to propose the extension to the research on bone awls and stilues, collected at the Early Medieval sites, to functional analysis. The applied methods were the experiments concerning the use of the replicas of those tools like perforating hides and linen, grinding, writing on wax tablets and the experiment investigating the traces related to post-depositional processes. Subsequently, each replica was examined on the macroscopic and microscopic level, using the high power analysis. It was found that the use-wear analysis enables to point out clear distinctions in use-wear traces which gives possibility of the functional classification and of applying this method to the artifacts found on the early medieval sites in future.

Translated by Monika Stelmasiak 